\title{
Does relationship lending promote growth? Savings banks and SME financing*
}

\author{
Constantin F. Slotty ${ }^{\ddagger} \dagger$ \\ Goethe University Frankfurt, House of Finance, Germany
}

First Draft: January 2009. This Version: April 2009

\begin{abstract}
This paper addresses the question whether close borrower-lender relationships, so called hausbank-relationships, facilitate the funding and beneficial development of SME. To this end, we derive a model which relates a firm's growth rate to its need for external funds and subsequently compute the firms that exceed their predicted growth rate. We then use this measure to identify specific characteristics that are associated with long- and short-term financing of firm growth, in particular the influence of relationship lending. We find that close ties with savings banks predict firms' access to external finance to fund growth. Moreover, the long-term liabilities of firms with hausbank-relationships almost double those with multiple relationships while the overall leverage is about the same. In turn, we find an strong empirical relationship between the provision of long-term funds and firm growth.
\end{abstract}

Keywords: Small business lending, credit access, public banks

JEL Codes: G21, D21

\footnotetext{
*This research paper is part of a project funded by the German Savings Bank Association. The expressed opinions are strictly those of the author and do not necessarily reflect those of the affiliated organizations.

${ }^{\ddagger}$ Goethe University Frankfurt, House of Finance, Email: slotty@finance.uni-frankfurt.de

${ }^{\dagger}$ I thank Michael Koetter for helpful discussion.
} 


\section{Introduction}

We aim to provide empirical evidence on the apparent conundrum regarding public bank's contribution to the performance of small and medium enterprises (SME). Specifically, we test one of the main reasons put forward by savings banks in respect to their beneficial impact on the business landscape in a developed economy: do German savings banks facilitate the funding and beneficial development of SME?

The role of banks to provide corporate firms with access to financial funds remains crucial in most developed economies (Hackethal, Schmidt, and Tyrell 1999). Specifically SME, which frequently form the backbone of the economy, rely on banks to fuel their growth (Berger, Klapper, and Udell 2001; Samitas and Kenourgios 2004). According to Audretsch and Elston (2002), both the role of SMEs and banks is particularly important for the third largest economy of the world: Germany.

At the same time, the German banking system exhibits some distinct characteristics compared to other industrialized countries. Specifically, the share of total assets managed by publicly owned savings banks is relatively large (Koetter et al. 2006). The relative merits and concerns regarding public banks, however, continue to fuel a heated, and sometimes even ideological, debate among both practitioners and academics. But the scientific evidence provides mixed guidance to this debate. On the one hand, a number of studies report that public banks are less profitable and more risky than privately owned banks (Iannotta, Nocera, and Sironi 2007). On the other hand, other empirical studies that distinguish, for example, developed and developing countries find no significant relation between public ownership and profitability (Micco, Panizza, and Yanez 2007).

In response to the ongoing policy debate as well as the mixed economic evidence, public banks in general, and German savings banks in particular, highlight their contribution to the economy as follows: to establish and maintain steady relations especially with SME, which might otherwise be shut-off external sources of finance.

Theoretical evidence if intense bank-firm relationships are beneficial to the latter remains unclear a priori. Boot and Thakor (2000) illustrate the ambivalence of relationship banking. The lock-in effect can be to the firm's detriment: proprietary knowledge of borrower characteristics by the bank paired with less alternatives to evade re-negotiability of soft budget constraints of firms with few banking relations can jeopardize both banks' and firms' incentives. In turn, long-term relations can enhance the efficiency of credit 
contracts and may provide access to external funds during crises, too.

The empirical evidence on the relation between firm performance and bank-firm relations mirrors the theoretical ambiguity. For example, Berger et al. (2007) report for Indian state-owned banks that these do not serve opaque small borrowers significantly more often compared to other customer groups. In turn, they find evidence that corporates maintaining relations with state-owned banks have few bank relations and rely on these to a larger extent. In turn, D'Auria, Foglia, and Reedtz (2007) report for Italian banks that hausbank-relations enable firms to borrow at lower cost. Likewise, Cole (1998) finds for the U.S. that SME with existing relationships to banks are more likely to receive further credit, thus underpinning the value of private information generated by an arm's length potential lender. The ambiguity of the international empirical evidence is reflected by findings of Agarwal and Elston (2001) on German firm performance. While they report that German firms enjoy easier access to capital, their results do neither show higher profitability nor growth for these firms.

In light of the mixed empirical evidence, we attempt to provide insights based on confidential data obtained from the German Savings Bank Association. We seek to assess more directly the hypotheses that savings banks support especially more constrained SME and the question to what extent close borrower-lender relationships are beneficial to the development of these firms. The involvement of savings banks in this regard can consist of several layers; the channeling of government aids, continued operative business mentoring, provision of liquidity insurance in situations of unexpected borrower rating deterioration and long-term credit contracts. As suggested by Elsas (2005) we use the dependency on savings bank debt as proxy for hausbank-relationship and predict firms' excess growth based either only on internal or short-term funding.

Our findings indicate that a higher proportion of savings bank loans enhances firms to grow beyond rates which would be possible by internal or short-term financing only. These results hold up to different model specifications and hausbank-relationship proxies. Since our sample consists entirely of savings banks clients the results apply only to hausbankrelationships of firms with savings banks.

The outline of the paper is as follows. Section 2 introduces the data and summary statistics. Section 3 provides an overview over the measures of the constraint growth rates and examines the implications that arise for the SME in our sample. In section 4 
we present the methodology and discuss the variables used in the regressions. Our results are reported in section 5 and section 6 concludes.

\section{Data and summary statistics}

The firm-level data covers financial statements of SME from all federal states in Germany. Most of the firms in our sample are rather small (with average total assets of $€ 1,091,409$ ) thus reflecting a representative picture of the German SME landscape. The unbalanced sample consists of 467,033 firm observations averaged over the period from $1996-2006$ and has been provided by the German Savings Bank Association (DSGV). All firms in the sample are savings banks clients with differing degrees of savings bank loans. However, the data does not contain information about the number or type of the other lenders. For the gross domestic product (GDP) of the respective regions the data is complemented by the Federal and State statistical offices data (DeStatis). To control for the competitive behavior of savings banks in Germany we calculate Lerner indices from the financial statements of savings banks.

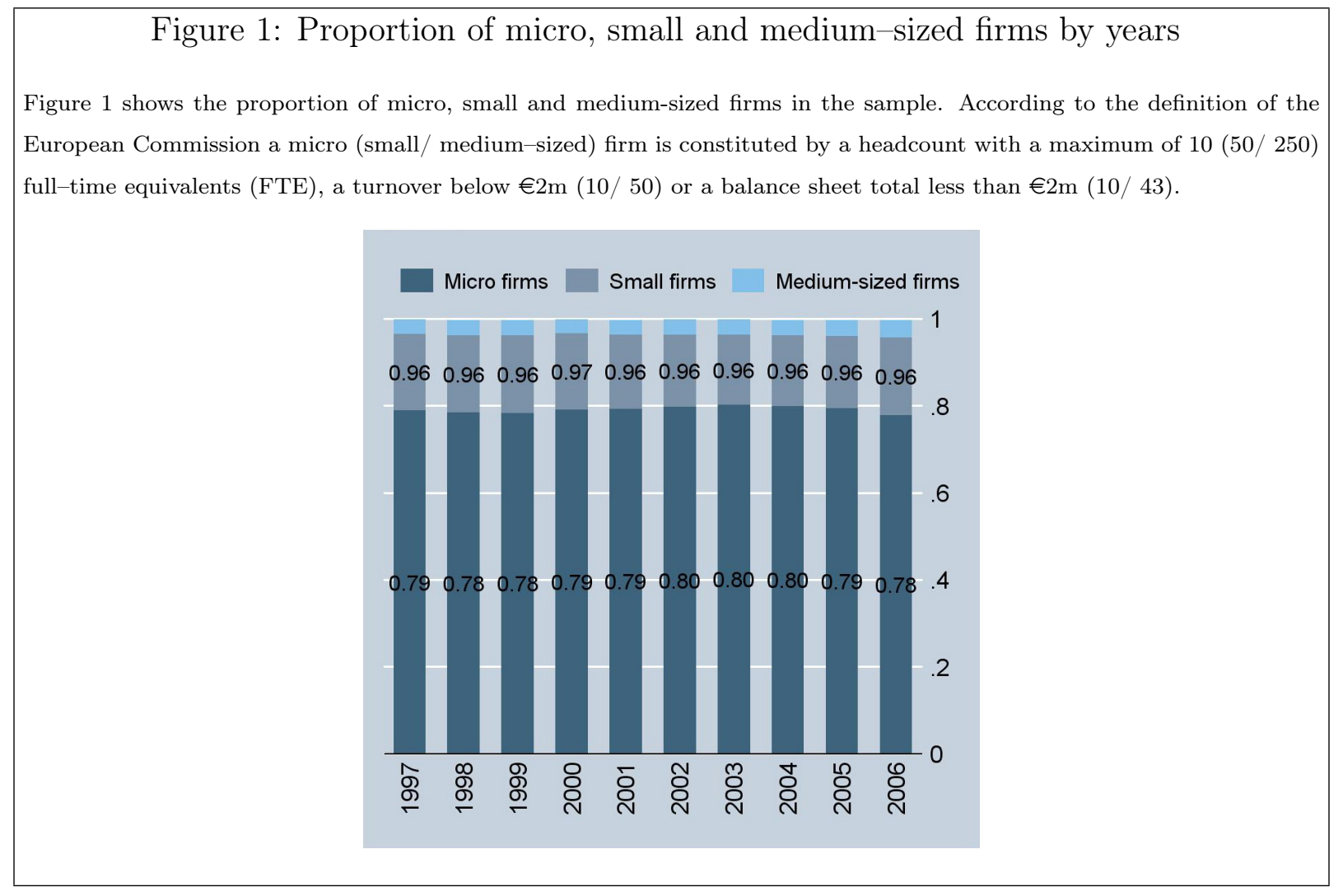

In Table 1 we present the median and mean values of a number of relevant features 


\begin{tabular}{|c|c|c|c|c|c|}
\hline $\begin{array}{l}\text { Table 1: Descript } \\
\text { Table } 1 \text { reports the medium and mean } \\
\text { dependency on savings banks, i.e. the } \\
\text { by total debt divided by total assets, } \\
\text { interest by interest expenses over tot } \\
\text { and lease expenses and trade credit b }\end{array}$ & $\begin{array}{l}\text { es by deg } \\
\text { alues (in pare } \\
\text { roportion of } \\
\text { ng term cred } \\
\text { debt, interes } \\
\text { accounts pay }\end{array}$ & $\begin{array}{l}\text { ee of dept } \\
\text { theses). The } \\
\text { avings bank } \\
\text { are all debt } \\
\text { coverage by } \\
\text { ble over total }\end{array}$ & $\begin{array}{l}\text { ndency or } \\
\text { gures are rep } \\
\text { ans to total } \\
\text { laturities ove } \\
\text { arnings befor } \\
\text { lebt. The tal }\end{array}$ & $\begin{array}{l}\text { Savings } \\
\text { ted in quarti } \\
\text { nk liabilities } \\
5 \text { years over } \\
\text { interest and } \\
\text { e comprises }\end{array}$ & $\begin{array}{l}\text { nk credit } \\
\text { s by the degr } \\
\text { The leverage } \\
\text { tal assets, a } \\
\text { axes (EBIT) } \\
7,033 \text { firm ol }\end{array}$ \\
\hline Median (mean) values & Savir & §s banks loan & to total banl & loans & \\
\hline $1996-2006$ & $<25 \%$ & $25 \%<50 \%$ & $50 \%<75 \%$ & $>75 \%$ & Average \\
\hline Leverage & $81.3 \%$ & $81.3 \%$ & $83.2 \%$ & $83.7 \%$ & $82.4 \%$ \\
\hline Long term credit & $\begin{array}{c}11.3 \% \\
(20.4 \%)\end{array}$ & $\begin{array}{c}10.0 \% \\
(18.2 \%)\end{array}$ & $\begin{array}{c}13.9 \% \\
(20.8 \%)\end{array}$ & $\begin{array}{c}21.8 \% \\
(28.2 \%)\end{array}$ & $\begin{array}{c}14.3 \% \\
(21.9 \%)\end{array}$ \\
\hline Average cost of interest & $\begin{array}{c}4.7 \% \\
(4.8 \%)\end{array}$ & $\begin{array}{c}4.8 \% \\
(4.8 \%)\end{array}$ & $\begin{array}{c}4.9 \% \\
(5.0 \%)\end{array}$ & $\begin{array}{c}5.0 \% \\
(5.0 \%)\end{array}$ & $\begin{array}{c}4.8 \% \\
(4.9 \%)\end{array}$ \\
\hline Interest Coverage & $\begin{array}{l}1.6 \mathrm{x} \\
(3.3 \mathrm{x})\end{array}$ & $\begin{array}{l}1.7 x \\
(3.7 x)\end{array}$ & $\begin{array}{l}1.8 \mathrm{x} \\
(3.9 \mathrm{x})\end{array}$ & $\begin{array}{c}2.1 \mathrm{x} \\
(5.5 \mathrm{x})\end{array}$ & $\begin{array}{c}1.8 \mathrm{x} \\
(4.1 \mathrm{x})\end{array}$ \\
\hline Trade credit & $\begin{array}{c}10.6 \% \\
(15.2 \%)\end{array}$ & $\begin{array}{c}11.9 \% \\
(16.6 \%)\end{array}$ & $\begin{array}{c}11.8 \% \\
(16.5 \%)\end{array}$ & $\begin{array}{c}9.9 \% \\
(15.6 \%)\end{array}$ & $\begin{array}{c}11.1 \% \\
(16.0 \%)\end{array}$ \\
\hline Total assets & $\begin{array}{c}1,810,996 \\
(8,105,090)\end{array}$ & $\begin{array}{c}1,170,000 \\
(4,137,974)\end{array}$ & $\begin{array}{c}835,000 \\
(2,773,842)\end{array}$ & $\begin{array}{c}549,639 \\
(1,594,725)\end{array}$ & $\begin{array}{c}1,091,409 \\
(4,152,908)\end{array}$ \\
\hline
\end{tabular}

of the SME in our sample. The values are averaged over the observation period and are reported by the degree of the credit-relationship with savings banks. First of all, we see that the SME in our sample are quite highly leveraged with a ratio of debt to total assets of $82 \%$ and average interest cost of $4.8 \%$. Although firms with a high share of savings banks loans pay marginally higher interest rates they seem to have less problems accommodating their financial obligations (including leases) as depicted by the higher interest coverage ratios. The use of trade credit with a median of $11 \%$ is rather low in comparison to SME in other economies such as Spain where short-term non-bank financing makes up about 65\% of total firm debt (González, Lopez, and Saurina 2007). The higher share of savings bank debt financing for small firms suggests that these firms are more likely to have hausbank-relationships with their respective savings bank (Elsas 2005). This suggestive evidence is further corroborated by the higher long-term credit ratios of companies with a share of savings banks financing above $75 \%$ which unperpin the long-term implicit contracts between a hausbank and its debtors. Table 2 provides a description of the nexus of capital intensity, return on assets before tax (RoA) and savings banks financing and puts these figures into perspective. 
Table 2: RoA (median) over states, savings banks dependency and capital intensity

Table 2 depicts the return on assets before tax (RoA) over the period 1996 - 2007 by federal states split into the capital-intensity (CI) of the respective firms and their share of savings bank loans of all bank loans. The CI, in turn, is calculated as the ratio of property, plant and equipment (PPE) to total assets by quartiles (e.g. CI 1 depicts firms with a ratio of PPE to total assets up to $25 \%$ ). On the right hand side the observations per state as well as the average RoA per state are reported.

\begin{tabular}{|c|c|c|c|c|c|c|c|c|c|c|c|c|c|c|c|c|c|c|}
\hline \multirow{2}{*}{$\begin{array}{l}1996-2006 \\
\text { State }\end{array}$} & \multicolumn{4}{|c|}{$25 \%<$ savings banks loans } & \multicolumn{4}{|c|}{$25 \%<50 \%$ savings banks loans } & \multicolumn{4}{|c|}{$50 \%<75 \%$ savings banks loans } & \multicolumn{4}{|c|}{$75 \%<100 \%$ savings banks loans } & \multirow[b]{2}{*}{ Obs } & \multirow[b]{2}{*}{ RoA } \\
\hline & CI 1 & CI 2 & CI 3 & CI 4 & CI 1 & CI 2 & CI 3 & CI 4 & CI 1 & CI 2 & CI 3 & CI 4 & CI 1 & CI 2 & CI 3 & CI 4 & & \\
\hline Schleswig-Holstein & $3.8 \%$ & $3.2 \%$ & $1.9 \%$ & $0.7 \%$ & $2.9 \%$ & $4.1 \%$ & $4.4 \%$ & $1.8 \%$ & $3.0 \%$ & $4.8 \%$ & $4.4 \%$ & $2.4 \%$ & $5.5 \%$ & $5.6 \%$ & $4.8 \%$ & $3.4 \%$ & 15,256 & $3.6 \%$ \\
\hline Lower Saxony & $2.8 \%$ & $3.8 \%$ & $3.6 \%$ & $1.2 \%$ & $3.5 \%$ & $4.3 \%$ & $4.0 \%$ & $2.1 \%$ & $3.4 \%$ & $4.4 \%$ & $4.8 \%$ & $2.3 \%$ & $5.2 \%$ & $5.5 \%$ & $4.5 \%$ & $2.8 \%$ & 49,125 & $3.6 \%$ \\
\hline $\begin{array}{l}\text { North } \\
\text { Westphalia }\end{array}$ & $3.1 \%$ & $4.3 \%$ & $3.6 \%$ & $1.6 \%$ & $4.0 \%$ & $4.7 \%$ & $3.7 \%$ & $2.0 \%$ & $4.2 \%$ & $5.6 \%$ & $4.7 \%$ & $3.0 \%$ & $5.9 \%$ & $6.6 \%$ & $6.1 \%$ & $3.8 \%$ & 63,087 & $4.2 \%$ \\
\hline Hesse & $2.7 \%$ & $3.5 \%$ & $3.1 \%$ & $1.5 \%$ & $3.1 \%$ & $3.8 \%$ & $3.2 \%$ & $1.4 \%$ & $3.5 \%$ & $4.8 \%$ & $3.9 \%$ & $2.6 \%$ & $4.9 \%$ & $4.9 \%$ & $4.8 \%$ & $4.0 \%$ & 42,423 & $3.5 \%$ \\
\hline Rhineland-Palatinate & $2.6 \%$ & $3.8 \%$ & $2.4 \%$ & $0.4 \%$ & $3.1 \%$ & $3.5 \%$ & $2.8 \%$ & $1.6 \%$ & $3.5 \%$ & $4.1 \%$ & $4.7 \%$ & $2.1 \%$ & $5.5 \%$ & $5.9 \%$ & $5.4 \%$ & $3.3 \%$ & 32,363 & $3.4 \%$ \\
\hline Saarland & $2.1 \%$ & $3.2 \%$ & $2.1 \%$ & $1.9 \%$ & $3.1 \%$ & $4.8 \%$ & $2.4 \%$ & $1.5 \%$ & $2.9 \%$ & $4.4 \%$ & $2.4 \%$ & $2.6 \%$ & $4.2 \%$ & $4.3 \%$ & $4.0 \%$ & $3.2 \%$ & 11,457 & $3.1 \%$ \\
\hline Baden-Württel & $3.5 \%$ & $4.1 \%$ & $3.9 \%$ & $2.4 \%$ & $3.7 \%$ & $5.1 \%$ & $4.7 \%$ & $2.6 \%$ & $4.1 \%$ & $5.7 \%$ & $5.2 \%$ & $3.5 \%$ & $6.5 \%$ & $7.0 \%$ & $6.0 \%$ & $4.7 \%$ & 109,157 & $4.5 \%$ \\
\hline Bavaria & $2.8 \%$ & $3.5 \%$ & $3.3 \%$ & $1.7 \%$ & $3.2 \%$ & $4.4 \%$ & $4.6 \%$ & $2.0 \%$ & $3.6 \%$ & $4.5 \%$ & $4.8 \%$ & $2.7 \%$ & $5.6 \%$ & $6.2 \%$ & $6.1 \%$ & $4.1 \%$ & 109,084 & $3.9 \%$ \\
\hline Obs West & 21,932 & 15,908 & 10,980 & 5,808 & 22,671 & 15,044 & 8,543 & 4,517 & 26,973 & 17,187 & 10,133 & 5,026 & 135,600 & 73,974 & 54,905 & 37,023 & 431,952 & - \\
\hline Average West & $2.9 \%$ & $3.7 \%$ & $3.0 \%$ & $1.4 \%$ & $3.3 \%$ & $4.3 \%$ & $3.7 \%$ & $1.9 \%$ & $3.5 \%$ & $4.8 \%$ & $4.4 \%$ & $2.6 \%$ & $5.4 \%$ & $5.8 \%$ & $5.2 \%$ & $3.7 \%$ & - & $3.7 \%$ \\
\hline $\begin{array}{l}\text { Mecklenburg- } \\
\text { Western Pomerania }\end{array}$ & $1.4 \%$ & $3.8 \%$ & $2.1 \%$ & $1.4 \%$ & $3.6 \%$ & $4.2 \%$ & $6.5 \%$ & $0.7 \%$ & $2.1 \%$ & $3.8 \%$ & $4.6 \%$ & $0.0 \%$ & $3.8 \%$ & $4.0 \%$ & $4.2 \%$ & $2.3 \%$ & 1,703 & $3.0 \%$ \\
\hline Brandenburg & $.8 \%$ & $2.1 \%$ & $1.9 \%$ & $-0.2 \%$ & $2.6 \%$ & $3.4 \%$ & $2.8 \%$ & $0.2 \%$ & $2.2 \%$ & $3.0 \%$ & $3.3 \%$ & $1.1 \%$ & $3.2 \%$ & $3.8 \%$ & $2.5 \%$ & $1.7 \%$ & 11,225 & $2.3 \%$ \\
\hline Saxony-Anhalt & $1.9 \%$ & $2.1 \%$ & $1.9 \%$ & $0.5 \%$ & $3.2 \%$ & $2.7 \%$ & $3.2 \%$ & $0.5 \%$ & $2.5 \%$ & $3.4 \%$ & $2.4 \%$ & $1.1 \%$ & $2.7 \%$ & $3.1 \%$ & $2.7 \%$ & $1.4 \%$ & 12,861 & $2.2 \%$ \\
\hline Thuringia & $2.6 \%$ & $1.9 \%$ & $2.7 \%$ & $0.2 \%$ & $3.2 \%$ & $4.2 \%$ & $3.3 \%$ & $0.8 \%$ & $3.1 \%$ & $3.5 \%$ & $3.0 \%$ & $3.1 \%$ & $3.3 \%$ & $3.2 \%$ & $3.2 \%$ & $1.9 \%$ & 7,677 & $2.7 \%$ \\
\hline Saxony & $1.8 \%$ & $3.3 \%$ & $2.1 \%$ & $0.3 \%$ & $3.2 \%$ & $3.4 \%$ & $3.1 \%$ & $1.3 \%$ & $4.3 \%$ & $3.4 \%$ & $4.8 \%$ & $2.1 \%$ & $4.5 \%$ & $4.1 \%$ & $3.6 \%$ & $2.6 \%$ & 15,792 & $3.0 \%$ \\
\hline Obs East & 1,574 & 1,984 & 1,740 & 1,212 & 1,663 & 1,914 & 1,260 & 686 & 2,084 & 2,397 & 1,721 & 725 & 8,688 & 8,824 & 7,739 & 5,047 & 49,258 & - \\
\hline Average East & $2.1 \%$ & $2.6 \%$ & $2.1 \%$ & $0.4 \%$ & $3.2 \%$ & $3.6 \%$ & $3.8 \%$ & $0.7 \%$ & $2.8 \%$ & $3.4 \%$ & $3.6 \%$ & $1.5 \%$ & $3.5 \%$ & $3.7 \%$ & $3.3 \%$ & $2.0 \%$ & - & $2.6 \%$ \\
\hline Obs All & 23,506 & 17,892 & 12,720 & 7,020 & 24,334 & 16,958 & 9,803 & 5,203 & 29,057 & 19,584 & 11,854 & 5,751 & 144,288 & 82,798 & 62,644 & 42,070 & 481,210 & - \\
\hline Average All & $2.5 \%$ & $3.2 \%$ & $2.6 \%$ & $0.9 \%$ & $3.2 \%$ & $4.0 \%$ & $3.8 \%$ & $1.3 \%$ & $3.2 \%$ & $4.1 \%$ & $4.0 \%$ & $2.1 \%$ & $4.4 \%$ & $4.7 \%$ & $4.2 \%$ & $2.8 \%$ & 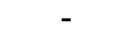 & $3.2 \%$ \\
\hline
\end{tabular}


An inspection yields several interesting findings: First, we see that firms with a capital intensity in the second quartile (a proportion of fixed assets to total assets of $25 \%<50 \%$ ) are in almost every state and every proportion of savings banks loans the most profitable companies in the sample. To find an explanation for this finding it would be interesting to consider the industries that lie within this capital intensity range to draw conclusions. However, due to the anonymized nature of the sample this information was not available. Secondly, the average profitability within each capital intensity quartile rises with the proportion of savings banks loans. Since we know, that these firms have a closer borrowerlender-relationship with at least one bank, a possible explanation could be that better access to external financing enables them to seize profitable investment opportunities which, in turn, leads to higher RoA's. Lastly, we observe that firms in the western regions of Germany have a higher average profitability of $0.9 \%$ which could be driven by a slower growth of the economy in the eastern states (Ludwig 2006). ${ }^{1}$

\section{Measures of firm growth capacity}

Our aim is to examine the impact of close borrower-lender relationships with savings banks on financial constraints and ultimately firm growth. However, firms are not equally affected by the presence of financial constraints. First, companies with sufficient cash flows from operations to fund profitable investments are less affected than firms whose internal resources do not suffice to accommodate their financial requirements. Second, in the vein of Rajan and Zingales (1998) firms from some industries have higher equilibrium leverage ratios. Ideally, we would therefore differentiate, say, capital intensive manufacturing firms from service oriented business. Due to missing data on industry codes, we therefore estimate a predicted growth rate for each firm, relying either only on its internal funds or on short-term financing. Then, to assess whether better access to external funding enables firms to seize growth opportunities, we first need to identify firms that require external financing and investigate whether their realized growth is contingent on the provision of

\footnotetext{
${ }^{1}$ To test whether the median of the RoA's in the respective groups are in fact different of each other we conduct a two-sample Wilcoxon rank-sum (Mann-Whitney) test. The $H_{0}$-Hypothesis is that the median of the RoA in the fourth quartile $(75 \%<100 \%$ savings banks loans) is the same as the one in the remaining groups $(0 \%<75 \%$ savings banks loans). The test results give strong evidence to reject the null hypothesis (significant at the $1 \%$ level) suggesting that the higher median RoA's for firms with a proportion of savings bank loans above $75 \%$ are not caused by random fluctuation.
} 
(long-term) financing by savings banks. ${ }^{2}$

Demirgüç-Kunt and Maksimovic (1998) point out that both the firm's cash flow and its optimal investment level are endogeneous. They illustrate this proposition by the example of a capital intensive firm which is in need of larger investment expenditures to fund further growth. If the firm's products face high demand or the market power of that company is sufficiently high, it may be able to finance its growth only from internal resources. Another firm, on the other hand, with the same properties but facing less favorable prospects may need external financing in order to attain the same growth rate.

To account for this endogeneity, we use two types of predicted firm growth. First, a measure that predicts the maximum growth rate if a firm only relies on its internal funds and second a measure for firms that can also resort to short-term financing. Subsequently, we test the hypothesis that firms which experience sufficient demand can exceed their predicted growth rates by obtaining (long-term) savings banks financing. In the development of the model we follow suggestions of cross-country firm-level studies by Demirgüç-Kunt and Maksimovic (1998, 2002). First, we derive a growth measure based on Higgins (1977) which describes the maximum growth if a firm retains all earnings and finances investment only from internal sources of finance (constraints on short- and long-term financing). This internal growth rate $I G R$ equals:

$$
I G R_{i t}=\mathrm{RoA}_{i t} /\left(1-\mathrm{RoA}_{i t}\right)
$$

where $R o A$ denotes return on assets. In turn, if firms use also short-term funding to fund growth, the second firm growth benchmark equals the firms return on long-term assets $L T A$, where the latter equals total assets less short-term debt:

$$
S G R_{i t}=\operatorname{RoLTA}_{i t} /\left(1-\operatorname{RoLTA}_{i t}\right)
$$

Based on equations (1) and (2), we then follow Demirgüç-Kunt and Maksimovic (2002) and create for each firm $i$ in region $r$ at time $t$ an indicator variable, whether realized growth exceeded predicted growth.

\footnotetext{
${ }^{2}$ As a further robustness check we also followed Rajan and Zingales (1998) who calculated benchmark growth rates based on industry codes. We attempted to substitute these by benchmark growth rates based on quartiles of capital intensity and regional differences. However, the results came out inconclusive which suggests that this measure is too crude to predict the appropriate growth rate for industries within a given capital intensity.
} 
However, the eventual existence of spare capacity in firm's production process poses a potential problem to our model. We attempt to mitigate this problem by averaging the afore generated indicator variables over all observations for each firm in order to smooth out production. Thus for each firm we obtain one measure for the excess growth with internal and one for short-term funding. This variable is in turn used as dependent variable in a regression model, which is explained by the proportion of savings banks credit of the respective firm and further control variables.

Further, our model makes several assumptions which may underestimate the maximum attainable growth rate and overestimate its cost; it assumes that the firms' use of their unconstrained sources of finance in relation to total assets does not change over the observation period and that the production technology desists from advancements that might reduce the cost of replacement investments.

Table 3 presents for each firm size category and by federal states the proportion of firms which exceed their internal and short-term growth rates. We derive these figures by first calculating a dummy variable for each firm and year, that equals one if the annual growth rate of sales exceeds the maximum attainable internal $\left(I G R_{i t}\right)$ or short-term borrowing $\left(S G R_{i t}\right)$ growth rate respectively. Thus, we obtain the dummy variable $\left(S T G R O_{i t}\right)$ if a firm exceeds its internal growth rate and $\left(L T G R O_{i t}\right)$ if a firm exceeds its short-term financed growth rate in a given year. Subsequently, the dummy variables are averaged over the observation period to obtain a metrical scaled variable for each firm ranging from 0 to 1 .

By using the same firm size classification as the European Commission, Table 3 examines whether firms of different size also exhibit different growth properties. We see that approximately $40 \%$ of all firms in our sample exceed their internal growth rates. Larger firms tend to exceed their growth rates (IGR and SGR) more often than smaller firms, potentially due to easier access to finance to facilitate growth. Moreover, a higher proportion of firms in the eastern regions of Germany exceed their growth rates in comparison to the western states ( $48.5 \%$ vs. $42.7 \%$ for IGR and $44.8 \%$ vs. $36.3 \%$ for SGR). This may be due to lower levels from which eastern firms start to grow accordingly faster. As Demirgüç-Kunt and Maksimovic (1998) noted, access to long-term financing seems to be particularly important for (large) German firms. Our sample of smaller firms exhibits similiar properties; if we take, for instance, the $33.2 \%$ of micro SME in the western regions 
Table 3: Proportion of firms growing faster than predicted

Table 3 presents the proportion of firms by states whose mean annual growth rate of sales exceeds the means of their constrained growth rates (IGR and SGR). For each firm the internal growth rate $\left(I G R_{t}\right.$ is given by $\left(R o A_{t} /\left(1-R_{o} A_{t}\right)\right)$ where $R o A_{t}$ is the firm's return on assets before tax. Maximum short-term financed growth rate $\left(S G R_{t}\right)$ is defined as $\operatorname{RoLT} A_{t} /\left(1-\operatorname{RoLT} A_{t}\right)$ where $\operatorname{RoLT} A_{t}$ is the ratio of earnings before tax to long-term capital. The firms are divided into three different size ranges in accordance with the definition of the European Commission. A micro (small/ medium-sized) SME is constituted by a headcount with a maximum of $10(50 / 250)$ full-time equivalents (FTE), a turnover below $€ 2 \mathrm{~m}$ $(10 / 50)$ or a balance sheet total less than $€ 2 \mathrm{~m}(10 / 43)$.

\begin{tabular}{|c|c|c|c|c|c|c|}
\hline \multirow{3}{*}{$\begin{array}{l}1996-2006 \\
\text { State }\end{array}$} & \multicolumn{6}{|c|}{ Proportion of firms that exceed their: } \\
\hline & \multicolumn{3}{|c|}{$\begin{array}{l}\text { Internal growth rate } \\
\text { IGR }=\text { RoA } /(1-R o A)\end{array}$} & \multicolumn{3}{|c|}{$\begin{array}{c}\text { Short-term financed growth rate } \\
\quad \mathrm{SGR}=\text { RoLTA } /(1-\text { RoLTA })\end{array}$} \\
\hline & Micro & Small & Medium & Micro & Small & Medium \\
\hline Schleswig-Holstein & $31.9 \%$ & $46.7 \%$ & $43.7 \%$ & $28.7 \%$ & $40.9 \%$ & $36.8 \%$ \\
\hline Lower Saxony & $33.7 \%$ & $45.6 \%$ & $49.5 \%$ & $30.0 \%$ & $38.9 \%$ & $40.6 \%$ \\
\hline North Rhine-Westphalia & $32.4 \%$ & $44.4 \%$ & $46.0 \%$ & $27.8 \%$ & $36.4 \%$ & $36.0 \%$ \\
\hline Hesse & $32.9 \%$ & $45.2 \%$ & $46.3 \%$ & $29.2 \%$ & $38.7 \%$ & $38.4 \%$ \\
\hline Rhineland-Palatinate & $32.9 \%$ & $47.7 \%$ & $51.1 \%$ & $28.9 \%$ & $40.8 \%$ & $43.3 \%$ \\
\hline Saarland & $38.0 \%$ & $48.2 \%$ & $55.6 \%$ & $34.6 \%$ & $41.3 \%$ & $45.4 \%$ \\
\hline Baden-Württemberg & $32.1 \%$ & $47.1 \%$ & $49.0 \%$ & $27.4 \%$ & $39.8 \%$ & $39.1 \%$ \\
\hline Bavaria & $31.9 \%$ & $45.9 \%$ & $47.8 \%$ & $28.3 \%$ & $39.0 \%$ & $39.2 \%$ \\
\hline Obs West & 369,042 & 79,443 & 16,795 & 369,042 & 79,443 & 16,795 \\
\hline Average West & $33.2 \%$ & $46.3 \%$ & $48.6 \%$ & $29.4 \%$ & $39.5 \%$ & $39.9 \%$ \\
\hline Mecklenburg-Western Pomerania & $33.7 \%$ & $58.9 \%$ & $64.5 \%$ & $30.6 \%$ & $56.1 \%$ & $64.5 \%$ \\
\hline Brandenburg & $36.6 \%$ & $49.3 \%$ & $52.6 \%$ & $34.0 \%$ & $45.2 \%$ & $49.3 \%$ \\
\hline Saxony-Anhalt & $36.6 \%$ & $51.1 \%$ & $56.2 \%$ & $34.4 \%$ & $46.6 \%$ & $51.7 \%$ \\
\hline Thuringia & $35.8 \%$ & $51.1 \%$ & $58.3 \%$ & $32.5 \%$ & $47.0 \%$ & $51.0 \%$ \\
\hline Saxony & $35.3 \%$ & $50.9 \%$ & $55.7 \%$ & $32.0 \%$ & $45.9 \%$ & $50.6 \%$ \\
\hline Obs East & 43,360 & 9,204 & 1,625 & 43,360 & 9,204 & 1,625 \\
\hline Average East & $35.6 \%$ & $52.3 \%$ & $57.5 \%$ & $32.7 \%$ & $48.2 \%$ & $53.4 \%$ \\
\hline Obs All & 412,402 & 88,647 & 18,420 & 412,402 & 88,647 & 18,420 \\
\hline Average All & $34.4 \%$ & $49.3 \%$ & $53.0 \%$ & $31.0 \%$ & $43.8 \%$ & $46.6 \%$ \\
\hline
\end{tabular}

in Table 3 which required some form of external financing over the sample period, then only $3.8 \%(33.2 \%-29.4 \%)$ could finance their growth entirely by using only short-term debt. Thus, access to external long-term financing seems to be vital for firms to fund their growth.

In addition to firm size effects on growth, it is ultimately the impact of hausbankrelationships we are interested in. In Table 4 we examine the constraint growth rates $S G R$ and $I G R$ by the proportion of savings bank loans to total loans and by federal states. We see that the pattern of rising predicted growth rates of eastern and western German states by the proportion of savings banks loans is similar to the observed values for the RoA's in Table 2. Moreover, the majority of firms $(52.7 \%)$ in our sample seem to have close ties with their savings bank as depicted by the high number of companies in the 10th decile. Strikingly, the growth rates $S G R$ as well as $I G R$ increase almost monotonically for each state; the mean values of $S G R$ and $I G R$ roughly double from the 1st to the 10th decile. This finding leads to the question whether the higher predicted 


\begin{tabular}{|c|c|c|c|c|c|c|c|c|c|c|c|c|}
\hline \multicolumn{13}{|c|}{$\begin{array}{l}\text { Table } 4 \text { presents the short-term (SGR) and internal (IGR) financed growth rates of firms by dec } \\
\text { to total bank loans. The first row in each federal state presents the SGR and the second row th } \\
\text { right the higher the proportion of savings banks loans to total bank loans. Column "10", for inst } \\
\text { IGR of firms with over } 90 \% \text { savings banks loans for each state respectively. }\end{array}$} \\
\hline \multirow{2}{*}{$\begin{array}{l}\text { 1996-2006 } \\
\text { State (SGR/ IGR) }\end{array}$} & \multicolumn{12}{|c|}{ Proportion of savings bank loans to total bank loans in deciles } \\
\hline & 1 & 2 & 3 & 4 & 5 & 6 & 7 & 8 & 9 & 10 & $\begin{array}{l}\text { N. of } \\
\text { Obs. }\end{array}$ & Mean \\
\hline \multirow[t]{2}{*}{ Schleswig-Holstein } & $5.0 \%$ & $5.8 \%$ & $6.4 \%$ & $7.7 \%$ & $6.8 \%$ & $7.7 \%$ & $6.7 \%$ & $8.0 \%$ & $8.1 \%$ & $8.7 \%$ & 15,089 & $7.1 \%$ \\
\hline & $2.6 \%$ & $2.7 \%$ & $3.5 \%$ & $4.1 \%$ & $3.4 \%$ & $4.1 \%$ & $3.6 \%$ & $4.4 \%$ & $4.7 \%$ & $5.5 \%$ & & $3.9 \%$ \\
\hline \multirow[t]{2}{*}{ Lower Saxony } & $6.3 \%$ & $7.3 \%$ & $6.6 \%$ & $8.9 \%$ & $8.5 \%$ & $8.0 \%$ & $8.0 \%$ & $9.0 \%$ & $8.4 \%$ & $8.9 \%$ & 48,616 & $8.0 \%$ \\
\hline & $3.2 \%$ & $3.5 \%$ & $3.1 \%$ & $4.1 \%$ & $3.9 \%$ & $4.0 \%$ & $4.0 \%$ & $4.6 \%$ & $4.3 \%$ & $5.3 \%$ & & $4.0 \%$ \\
\hline \multirow{2}{*}{$\begin{array}{l}\text { North Rhine- } \\
\text { Westphalia }\end{array}$} & $6.7 \%$ & $7.3 \%$ & $7.8 \%$ & $8.7 \%$ & $9.0 \%$ & $9.1 \%$ & $10.8 \%$ & $10.7 \%$ & $11.2 \%$ & $11.7 \%$ & 62,652 & $9.3 \%$ \\
\hline & $3.2 \%$ & $3.7 \%$ & $3.9 \%$ & $4.2 \%$ & $4.3 \%$ & $4.5 \%$ & $5.2 \%$ & $5.1 \%$ & $5.6 \%$ & $6.6 \%$ & & $4.6 \%$ \\
\hline \multirow[t]{2}{*}{ Hesse } & $6.4 \%$ & $6.2 \%$ & $7.2 \%$ & $6.6 \%$ & $6.8 \%$ & $6.8 \%$ & $8.5 \%$ & $8.8 \%$ & $8.9 \%$ & $8.7 \%$ & 42,068 & $7.5 \%$ \\
\hline & $2.9 \%$ & $3.1 \%$ & $3.3 \%$ & $3.3 \%$ & $3.4 \%$ & $3.5 \%$ & $4.1 \%$ & $4.6 \%$ & $4.7 \%$ & $5.2 \%$ & & $3.8 \%$ \\
\hline \multirow[t]{2}{*}{ Rhineland-Palatinate } & $5.5 \%$ & $6.6 \%$ & $6.5 \%$ & $6.5 \%$ & $7.1 \%$ & $6.9 \%$ & $9.2 \%$ & $8.7 \%$ & $9.6 \%$ & $9.9 \%$ & 32,046 & $7.7 \%$ \\
\hline & $2.7 \%$ & $3.2 \%$ & $2.7 \%$ & $3.1 \%$ & $3.2 \%$ & $3.3 \%$ & $4.4 \%$ & $4.5 \%$ & $5.0 \%$ & $5.9 \%$ & & $3.8 \%$ \\
\hline \multirow[t]{2}{*}{ Saarland } & $5.1 \%$ & $5.2 \%$ & $7.9 \%$ & $7.1 \%$ & $6.5 \%$ & $5.6 \%$ & $7.7 \%$ & $8.2 \%$ & $8.0 \%$ & $8.3 \%$ & 11,439 & $7.0 \%$ \\
\hline & $2.2 \%$ & $2.6 \%$ & $3.4 \%$ & $3.3 \%$ & $3.0 \%$ & $2.3 \%$ & $3.3 \%$ & $3.7 \%$ & $4.0 \%$ & $4.6 \%$ & & $3.2 \%$ \\
\hline \multirow[t]{2}{*}{ Baden-Württemberg } & $7.4 \%$ & $8.2 \%$ & $8.5 \%$ & $9.5 \%$ & $9.1 \%$ & $9.5 \%$ & $10.0 \%$ & $10.8 \%$ & $10.7 \%$ & $12.5 \%$ & 108,604 & $9.6 \%$ \\
\hline & $3.7 \%$ & $4.0 \%$ & $4.3 \%$ & $4.5 \%$ & $4.4 \%$ & $4.8 \%$ & $5.0 \%$ & $5.6 \%$ & $5.7 \%$ & $7.2 \%$ & & $4.9 \%$ \\
\hline \multirow[t]{2}{*}{ Bavaria } & $6.2 \%$ & $6.9 \%$ & $6.5 \%$ & $7.4 \%$ & $8.5 \%$ & $8.2 \%$ & $7.9 \%$ & $8.6 \%$ & $8.9 \%$ & $10.9 \%$ & 108,152 & $8.0 \%$ \\
\hline & $3.1 \%$ & $3.3 \%$ & $3.2 \%$ & $3.7 \%$ & $4.2 \%$ & $4.1 \%$ & $4.2 \%$ & $4.5 \%$ & $4.9 \%$ & $6.5 \%$ & & $4.2 \%$ \\
\hline Obs West & 21,426 & 19,246 & 18,490 & 18,451 & 19,047 & 20,033 & 22,555 & 26,029 & 35,112 & 228,277 & 428,666 & \\
\hline Mean SGR & $6.1 \%$ & $6.7 \%$ & $7.2 \%$ & $7.8 \%$ & $7.8 \%$ & $7.7 \%$ & $8.6 \%$ & $9.1 \%$ & $9.2 \%$ & $10.0 \%$ & & $8.0 \%$ \\
\hline Mean IGR & $3.0 \%$ & $3.3 \%$ & $3.4 \%$ & $3.8 \%$ & $3.7 \%$ & $3.8 \%$ & $4.2 \%$ & $4.6 \%$ & $4.9 \%$ & $5.8 \%$ & & $4.1 \%$ \\
\hline \multirow{2}{*}{$\begin{array}{l}\text { Mecklenburg- } \\
\text { Western Pomerania }\end{array}$} & $3.6 \%$ & $3.3 \%$ & $4.4 \%$ & $8.0 \%$ & $9.8 \%$ & $6.0 \%$ & $8.2 \%$ & $5.4 \%$ & $9.1 \%$ & $5.3 \%$ & 1,678 & $6.3 \%$ \\
\hline & $2.3 \%$ & $2.0 \%$ & $2.7 \%$ & $4.8 \%$ & $5.2 \%$ & $2.9 \%$ & $4.3 \%$ & $3.3 \%$ & $5.6 \%$ & $3.4 \%$ & & $3.7 \%$ \\
\hline \multirow[t]{2}{*}{ Brandenburg } & $1.5 \%$ & $2.5 \%$ & $5.3 \%$ & $6.9 \%$ & $4.7 \%$ & $6.1 \%$ & $5.5 \%$ & $4.8 \%$ & $5.6 \%$ & $5.0 \%$ & 11,097 & $4.8 \%$ \\
\hline & $1.0 \%$ & $1.5 \%$ & $2.6 \%$ & $2.8 \%$ & $2.3 \%$ & $3.1 \%$ & $3.0 \%$ & $2.8 \%$ & $3.1 \%$ & $3.1 \%$ & & $2.5 \%$ \\
\hline \multirow[t]{2}{*}{ Saxony-Anhalt } & $3.1 \%$ & $4.4 \%$ & $4.0 \%$ & $7.4 \%$ & $5.5 \%$ & $5.2 \%$ & $4.9 \%$ & $5.1 \%$ & $4.7 \%$ & $4.4 \%$ & 12,584 & $4.9 \%$ \\
\hline & $1.4 \%$ & $1.9 \%$ & $1.8 \%$ & $3.3 \%$ & $3.1 \%$ & $2.6 \%$ & $2.8 \%$ & $2.8 \%$ & $2.7 \%$ & $2.8 \%$ & & $2.5 \%$ \\
\hline \multirow[t]{2}{*}{ Thuringia } & $3.2 \%$ & $3.7 \%$ & $5.9 \%$ & $5.2 \%$ & $5.7 \%$ & $4.8 \%$ & $6.2 \%$ & $6.0 \%$ & $7.4 \%$ & $4.6 \%$ & 7,610 & $5.3 \%$ \\
\hline & $1.7 \%$ & $2.1 \%$ & $3.0 \%$ & $2.8 \%$ & $3.3 \%$ & $2.7 \%$ & $3.4 \%$ & $3.4 \%$ & $4.3 \%$ & $3.0 \%$ & & $3.0 \%$ \\
\hline \multirow[t]{2}{*}{ Saxony } & $2.9 \%$ & $5.8 \%$ & $5.8 \%$ & $6.5 \%$ & $5.9 \%$ & $6.4 \%$ & $7.9 \%$ & $7.7 \%$ & $7.4 \%$ & $5.8 \%$ & 15,582 & $6.2 \%$ \\
\hline & $1.5 \%$ & $3.1 \%$ & $2.7 \%$ & $3.3 \%$ & $3.1 \%$ & $3.7 \%$ & $4.4 \%$ & $4.5 \%$ & $4.3 \%$ & $3.8 \%$ & & $3.4 \%$ \\
\hline Obs East & 2,907 & 2,399 & 2,102 & 2,142 & 2,311 & 2,435 & 2,861 & 3,355 & 4,672 & 23,367 & 48,551 & \\
\hline Mean SGR & $2.9 \%$ & $3.9 \%$ & $5.1 \%$ & $6.8 \%$ & $6.3 \%$ & $5.7 \%$ & $6.5 \%$ & $5.8 \%$ & $6.8 \%$ & $5.0 \%$ & & $5.5 \%$ \\
\hline Mean IGR & $1.6 \%$ & $2.1 \%$ & $2.6 \%$ & $3.4 \%$ & $3.4 \%$ & $3.0 \%$ & $3.6 \%$ & $3.4 \%$ & $4.0 \%$ & $3.2 \%$ & & $3.0 \%$ \\
\hline Obs All & 24,333 & 21,645 & 20,592 & 20,593 & 21,358 & 22,468 & 25,416 & 29,384 & 39,784 & 251,644 & 477,217 & \\
\hline
\end{tabular}

growth rates also lead to higher excess growth for (augmented) savings bank financed SME. Table 5 attempts to give a first, descriptive insight. Likewise Table 3, we see that SME in the eastern states more often exceed their internal and short-term financed growth rates. Further, the spread of firms' internally and short-term financed excess growth rates yields some interesting findings: Throughout all deciles the spread between STGRO and LTGRO is higher in the western states. This suggests that on average firms in the eastern states have a greater exigency to fund their growth with long-term loans. Moreover, the spreads are declining for all states from the 1st to the 10th decile indicating that firms with a higher proportion of savings banks loans use long-term funding more often to 
finance their growth. Yet, the most apparent observation are the declining excess growth rates from the 1 st to the 10 th decile.

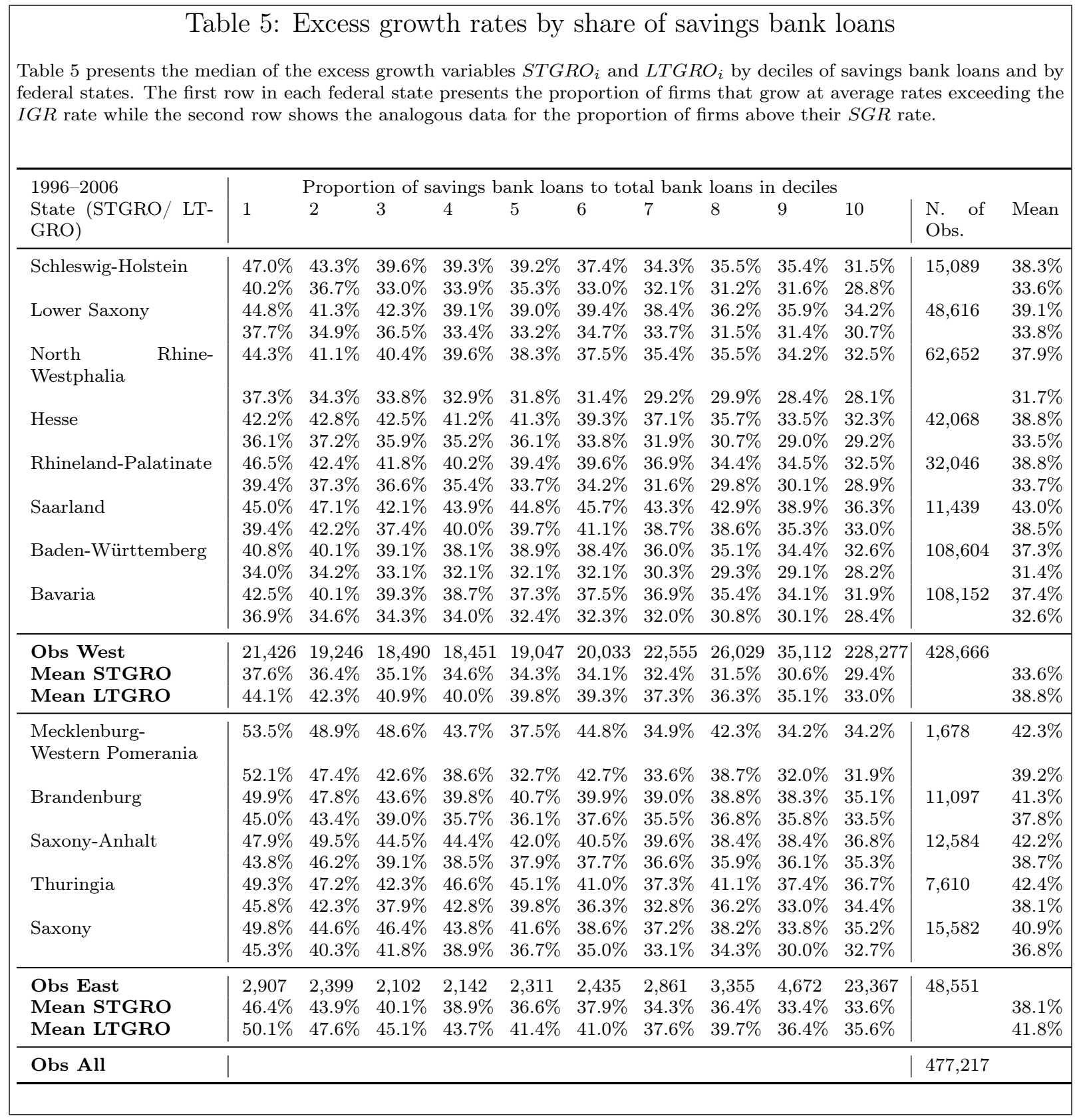

However, this apparently unambiguous relation may be misleading. Since Table 1 showed that savings banks primarily have hausbank-relationships (defined by a proportion of savings banks credits above 75\%) with smaller firms and Table 3 further revealed that larger firms have a greater tendency to grow above predicted rates, the relation in Table 5 could simply be driven by the size of firms. An answer to this puzzle can only be provided by a regression analysis that accounts for multiple factors and will be adressed in section 5 . 


\section{Methodology}

In this section we predict the afore generated variables which indicate whether firms grow above or below their internal and short-term financed growth rates. To this end, consider a standard logit model.

$$
P\left(Y_{i}=1 \mid X_{i}\right)=\frac{\exp \left(\alpha+\beta X_{i}+\gamma Z_{j}\right)}{1+\exp \left(\alpha+\beta X_{i}+\gamma Z_{j}\right)}
$$

where $P$ is the probability that firm $i$ will grow above benchmark growth. This likelihood is conditioned on $X_{i}$ a vector of explanatory variables (firm-specific covariates, state specific variables), $\alpha, \beta$, and $\gamma$ are parameters to be estimated. Given the large sample size, we first estimate below the logit model for each state separately and subsequently for the whole sample. Note that within each state we observe mostly multiple savings bank regions $j$. For these we therefore also include region-specific controls. As such our result is analogous to the cross-country perspective in Demirgüç-Kunt and Maksimovic (1998). For reasons of simplification, the right hand side of the equations presented within the following tables generally depicts the exponential term in our logit regression.

Firm characteristics $X$ We specify the following firm-specific variables. Our primary variable is the proportion of a firm's savings bank loans to all bank loans (SB). Whited (1992) found that financial constraints and thus, a diminished ability to access external financing, has a direct influence on firms' investment plans. Therefore our variable describes the dependency of a firm on its savings bank and aims to test whether hausbank-relationships help firms to seize their growth options.

The rationales for the benefits of close borrower-lender relationships are suggested in the financial intermediation literature: increased credit availability, intertemporal smoothing, enhancement of borrower's project payoffs and liquidity insurance as well as more efficient decisions in case of financial distress (e.g. Sharpe (1990), Petersen and Rajan (1995), Boot and Thakor (2000), Elsas (2005)). Since we consider two measures of contraint growth (STGRO and LTGRO) it would be conceivable that hausbank-relationships have a mixed impact. A positive relation, for instance, with firm growth relying only on internal funds but no significant relation with firm growth if firms also have access to short-term borrowing would indicate that savings banks on average only provide shortterm funding to their customers. Conversely, a significant relation for the savings bank 
variable and $L T G R O$ but not with $S T G R O$ would suggest that the provision of long-term financing is the crucial element of savings bank financing.

We also include several control variables. The variable SIZE is defined as the log of firm's total assets. Cross-country studies of financing choices by Demirgüç-Kunt and Maksimovic $(1999,2001)$ have found different patterns of financing for small and large firms in the use of long-term financing and trade credit. Further, larger firms may benefit from internal capital markets and face less financing constraints due to better access to capital markets, thus we would expect positive influence of size on firm growth. Moreover, since savings banks have a strong focus on smaller business entities (see Table 1) controlling for size is likely to be crucial to the results.

The variable leverage (LE) controls for a firm's debt structure and is measured as total debt obligations over total assets. Myers (1976) and Jensen (1986) predict that the leverage has an important influence on investment policy. In the model of Myers (1976), debt can give rise to an "overhang" effect, creating an incentive to reject projects that have positive net present value if the benefits from accepting the project accrue to the bondholders without also increasing shareholders' wealth. Jensen (1986), on the other hand, suggests that debt can serve a valuable bonding role, by limiting the ability of managers to invest in negative net present value projects. Furthermore, Barclay and Morellec (2006) posit that increasing growth options lead to a rise of the under-investment costs of debt and at the same time decreases the benefits of debt in mitigating the free cash flow problem. Hence, their results imply a negative relation between book leverage and growth options.

Capital intensity (CI) controls for different growth patters of industrial structures that are associated with either higher or lower investments in fixed assets. Generally, the entry barriers are higher for industries with high initial set-up costs and therefore competition may be less than in non-capital intensive industries, such as service or wholesale. This would imply a positive relation with firm's excess growth. On the other hand, firms with a high share of fixed assets may be particularly susceptible to credit rationing due to their higher financing demand for long-term assets and thus grow below-average when cut off from short- and/or long-term financing.

Lending choices are also conditional on general and local business conditions. In turn, 
regional indicators of financial development are of importance to economic growth as shown by Lucchetti, Papi, and Zazzaro (2001) and Koetter and Wedow (2006). Hence, we include in $Z$ regional macroeconomic and banking market covariates, too. In particular, we hypothesize that especially the competitive stance banks in the region affects access to financial funds (see e.g. Boyd and Nicolã (2005)). We use Lerner indices provided by Koetter and Vins (2008) to proxy banks' power to charge prices over marginal cost and thus the ability to enjoy some kind of market power. The indices are calculated as

$$
L=\frac{(A P+A C)-M C}{A P+A C}
$$

where $A P$ and $A C$ stand for average profits and average cost respectively which sum in average revenues. $M C$ denotes marginal cost (see Appendix, Table 11).

Petersen and Rajan (1994) hypothesize that banks with exclusive access to customers and some ability to conduct mark-up pricing reap rents. This would suggest that firms are less likely to grow above average when average Lerner indices are high in their region. However, as shown by Boot and Thakor (2000), when banks can engage both in relationship and arm's-length lending, the two types of lending can be substitutes. In particular, increased bank competition could render relationship lending more attractive for banks since it provides better insulation against price competition. One can further argue that a monopolistic market structure generally substitutes for relationship lending because this is an instrument to deliberately create bank monopoly power. The "market power" hypothesis which asserts that competition promotes credit availability is inconsistent with the "information" hypothesis put forth by Petersen and Rajan and thus the resolution is ultimately an empirical issue.

The variable GDP depicts the growth of the respective regional gross domestic product. It controls for possibility that the firms' ambition to fund excess growth externally is affected by the rate of growth of the regional economy. In a fast growing economy the rate of profit is likely to be high. This, in turn, will tend to increase the predicted growth rates IGR and SGR allowing for faster growth without the dependence on external finance. 


\section{Results}

The regressions in Table 6 and 7 investigate whether firms which exceed their internally and short-term financed growth rate require external financing. The dependent variables are $S T G R O_{i}$ and $L T G R O_{i}$ respectively. We start with the former and inspect first the variable firm size as proxy for a firms' access to capital markets. As we can see the variable is positive and significant at the $1 \%$ level for all federal states. This suggests that the properties that are associated with larger firm size enhance access to external capital which, in turn, is used to fund growth.

\section{Table 6: Constraints on short- and long-term external financing}

Table 6 reports the regression results of the logit model with $S T G R O_{i}$ as dependent variable. $S T G R O_{i}$ is calculated as the proportion of years for each firm in which the sales growth exceeded the predicted growth rate if a firm funds its growth internally. Since we observed in the data that firms have either excess growth or no excess growth in each year of the observation period the mean values over the years are for about half of the firms in the sample either zero or one; therefore we choose a logit approach to model the relationship. Furthermore, we control for regional differences in the federal states by using dummy variables for different regions within each state (not reported). The estimated model is $S_{\text {TGRO }}$ Firm $_{i}=$ $\alpha_{i}+\beta_{1} S B_{i}+\beta_{2} L E_{i}+\beta_{3} G D P_{i}+\beta_{4} L I_{i}+\beta_{5} C I_{i}+\beta_{6} S I Z E_{i}+\beta_{7} R E G_{j}+\epsilon_{i}$. The model is estimated with a robust Huber/White/sandwich estimator.

\begin{tabular}{|c|c|c|c|c|c|c|c|c|}
\hline $\begin{array}{l}1996-2006 \\
\text { State }\end{array}$ & Const. & $\begin{array}{l}\text { Savings } \\
\text { banks } \\
\text { credit }\end{array}$ & Leverage & $\begin{array}{l}\text { Regional } \\
\text { GDP }\end{array}$ & $\begin{array}{l}\text { Lerner } \\
\text { Index }\end{array}$ & $\begin{array}{l}\text { Capital } \\
\text { intensity }\end{array}$ & Size & $\begin{array}{l}\text { N. of } \\
\text { Obs. }\end{array}$ \\
\hline Schleswig-Holstein & $-9.800 * * *$ & $0.155^{* *}$ & $1.735^{* * *}$ & $2.725^{* *}$ & $2.224^{* * *}$ & -0.00396 & $0.686^{* * *}$ & 14,449 \\
\hline Lower Saxony & $-9.391 * * *$ & -0.0457 & $0.721^{* *}$ & -1.78 & $5.162^{* * *}$ & -0.142 & $0.654^{* * *}$ & 1,505 \\
\hline $\begin{array}{l}\text { North Rhine- } \\
\text { Westphalia }\end{array}$ & $-9.797 * * *$ & $0.127^{* * *}$ & $1.545^{* * *}$ & -0.395 & $1.752^{* * *}$ & $-0.301 * * *$ & $0.687^{* * *}$ & 46,625 \\
\hline Hesse & $-10.48^{* * *}$ & $0.471^{* * *}$ & $1.355^{* * *}$ & -0.819 & -0.0107 & 0.0535 & $0.809 * * *$ & 11,637 \\
\hline Rhineland-Palatinate & $-10.58^{* * *}$ & $0.225^{* *}$ & $1.452^{* * *}$ & $4.558^{* * *}$ & $-0.968^{*}$ & $-0.323^{* * *}$ & $0.797^{* * *}$ & 12,159 \\
\hline Saarland & $-9.239 * * *$ & $0.152^{* * *}$ & $1.581^{* * *}$ & 0.404 & $0.684^{* *}$ & $-0.221 * * *$ & $0.627^{* * *}$ & 62,872 \\
\hline Baden-Württemberg & $-7.822 * * *$ & -0.0634 & $1.699 * * *$ & $1.081^{*}$ & -0.229 & $-0.227 * * *$ & $0.554 * * *$ & 41,198 \\
\hline Bavaria & $-7.075 * * *$ & $0.222^{* *}$ & $1.232^{* * *}$ & -1.399 & -0.297 & $0.347^{* * *}$ & $0.537^{* * *}$ & 7,185 \\
\hline $\begin{array}{l}\text { Mecklenburg- } \\
\text { Western Pomerania }\end{array}$ & $-9.745^{* * *}$ & $0.262^{* * *}$ & $1.416^{* * *}$ & -0.648 & $-0.637^{*}$ & $0.434^{* * *}$ & $0.749 * * *$ & 15,706 \\
\hline Brandenburg & $-9.896 * * *$ & $0.269 * * *$ & $1.349^{* * *}$ & 0.93 & 0.348 & -0.0454 & $0.740 * * *$ & 31,068 \\
\hline Saxony-Anhalt & $-7.269 * * *$ & 0.0663 & $1.034^{* * *}$ & $-1.539^{*}$ & $5.540 * * *$ & -0.0285 & $0.529^{* * *}$ & 10,997 \\
\hline Thuringia & $-9.425 * * *$ & $0.184^{* * *}$ & $1.803^{* * *}$ & 0.245 & $1.026^{* * *}$ & $-0.218 * * *$ & $0.681 * * *$ & 105,908 \\
\hline Saxony & $-8.821^{* * *}$ & $0.106^{* * *}$ & $1.362^{* * *}$ & $1.767^{* * *}$ & $1.575^{* * *}$ & $-0.211^{* * *}$ & $0.648^{* * *}$ & 104,938 \\
\hline All & $-8.582^{* * *}$ & $0.141^{* * *}$ & $1.569 * * *$ & $0.791^{* * *}$ & $0.855^{* * *}$ & $-0.164 * * *$ & $0.655^{* * *}$ & 467,033 \\
\hline
\end{tabular}

Next we consider the capital intensity (CI) of firms. The share of fixed assets to total assets has a negative and significant (1\% level) impact on internally financed growth. This finding suggests that access to external capital is particularly important for capital intensive industries. Thus, firms with a higher share of fixed assets with no recourse to external short- and long-term capital find it harder to grow at rates that exceed their internal resources.

The variable Lerner index (LI) describes the market power of savings banks in their 
respective region and examines whether higher market power of savings banks is conducive or detrimental to firm growth. We find a positive and significant influence of the market power of savings banks on firm growth which is likely to reflect the better availability of credit in close borrower-lender relationships. These findings are consistent with those of Petersen and Rajan (1994), Zarutskie (2003) and Berger, Rosen, and Udell (2007) and corroborate the information hypothesis which states that less concentrated markets are associated with better credit availability because competitive banking markets can weaken relationship building by depriving banks of the incentive to invest in soft information.

Our next variable is the growth rate of the regional economy (GDP). As expected we find that a stronger growth of the local economy also spurs firms' excess growth due to increased availability of internal funds. The ambiguity of the relationship for some federal states in this regard is likely to be driven by the lack of variance of this variable in states which comprise only few regions; in the regression for the full sample, however, the variable is positive and significant at the $1 \%$ level.

The regression results also show that firms exceeding their internal growth rate base a higher share of their financial structure on debt. From the agency point of view, this relation is somewhat surprising. The agency theory predicts that high-growth firms are prone to reduce their reliance on debt financing in order to preserve financial flexibility for times when financing requirements are more urgent. Furthermore, the agency story also suggests that high-growth firms will employ less debt in order to avoid the underinvestment problem described in the previous section.

Our results are opposite to this conjecture, since we find that firms exceeding their $I G R$ and $S G R$ have both a higher leverage (LE) which suggests that firms use both short- and long-term debt to fund growth. This relation, however, is not unique to firms primarily financed by savings banks. Buch and Doepke (2008) report similiar findings for a sample of German firms over almost the exact observation period but using a firm-level dataset provided by the Deutsche Bundesbank. Hence, our explanation aims to account for the role of relationship lending for small firms and specific features of the financial system: Since access to capital markets is limited for small firms and particular in Germany which is often characterized as bank-based system (Krahnen and Schmidt 2004) high-growth firms may have moderate choices to finance their excess growth with other capital sources than additional bank credit in particular since the hold-up problem may be more severe for 
such firms. From a hausbank's point of view, the "soft"-information which was gathered over the duration of the relationship could provide a higher debt capacity due to refined contract terms (Berger and Udell 1995) than sole "hard"-information which is used when banks do not have had prior contact to the borrower. In addition, the discounted value of predicted future cash flows from firms' additional projects could also add to an extended debt capacity.

Our prime variable of interest, however, is the proportion of savings banks loans to total bank loans (SB). This relation is positive and significant at the $1 \%$ level suggesting that a higher share of savings banks loans enhances firm growth due to an increased availability of funds which, in turn, allows to realize growth options.

\section{Table 7: Constraints on long-term external financing}

Table 7 reports the regression results of the logit model with $L T G R O_{i}$ as dependent variable. $L T G R O_{i}$ is calculated as the proportion of years for each firm in which the sales growth exceeded the predicted growth rate if a firm funds its growth with internal cash-flows and short-term financing. Furthermore, we control for regional differences in the federal states by using dummy variables for different regions within each state (not reported). The estimated model is $L T G R O_{\text {Firm }}=\alpha_{i}$ $+\beta_{1} S B_{i}+\beta_{2} L E_{i}+\beta_{3} G D P_{i}+\beta_{4} L I_{i}+\beta_{5} C I_{i}+\beta_{6} S I Z E_{i}+\beta_{7} R E G_{j}+\epsilon_{i}$. The model is estimated with a robust Huber/White/sandwich estimator.

\begin{tabular}{|c|c|c|c|c|c|c|c|c|}
\hline $\begin{array}{l}1996-2006 \\
\text { State }\end{array}$ & Const. & $\begin{array}{l}\text { Savings } \\
\text { banks } \\
\text { credit }\end{array}$ & Leverage & $\begin{array}{l}\text { Regional } \\
\text { GDP }\end{array}$ & $\begin{array}{l}\text { Lerner } \\
\text { Index }\end{array}$ & $\begin{array}{l}\text { Capital } \\
\text { inten- } \\
\text { sity }\end{array}$ & Size & $\begin{array}{l}\text { N. of } \\
\text { Obs. }\end{array}$ \\
\hline Schleswig-Holstein & $-10.18^{* * *}$ & $0.397^{* * *}$ & $1.971^{* * *}$ & 0.894 & $2.569^{* * *}$ & $0.326^{* * *}$ & $0.659^{* * *}$ & 14,449 \\
\hline Lower Saxony & $-9.213^{* * *}$ & 0.141 & $0.735^{* *}$ & -0.362 & $4.133^{* *}$ & -0.0231 & $0.629^{* * *}$ & 1,505 \\
\hline $\begin{array}{ll}\text { North } & \text { Rhine- } \\
\text { Westphalia } & \end{array}$ & $-9.165 * * *$ & $0.231^{* * *}$ & $1.469 * * *$ & 0.134 & $2.061^{* * *}$ & $0.123^{* * *}$ & $0.585^{* * *}$ & 46,625 \\
\hline Hesse & $-10.69 * * *$ & $0.680^{* * *}$ & $1.396^{* * *}$ & 1.654 & -0.198 & $0.445^{* * *}$ & $0.773^{* * *}$ & 11,637 \\
\hline Rhineland-Palatinate & $-11.12^{* * *}$ & $0.527^{* * *}$ & $1.616^{* * *}$ & $4.346^{* * *}$ & 0.555 & -0.122 & $0.777^{* * *}$ & 12,159 \\
\hline Saarland & $-8.023^{* * *}$ & $0.269 * * *$ & $1.370^{* * *}$ & $1.049^{* *}$ & $0.874^{* * *}$ & $0.166^{* * *}$ & $0.510^{* * *}$ & 62,872 \\
\hline Baden-Württemberg & $-7.820^{* * *}$ & 0.05 & $1.556^{* * *}$ & 0.682 & 0.23 & $0.120^{* * *}$ & $0.513^{* * *}$ & 41,198 \\
\hline Bavaria & $-8.230^{* * *}$ & $0.282^{* * *}$ & $1.559^{* * *}$ & 0.437 & 0.818 & $0.567^{* * *}$ & $0.564^{* * *}$ & 7,185 \\
\hline $\begin{array}{l}\text { Mecklenburg- } \\
\text { Western Pomerania }\end{array}$ & $-9.579 * * *$ & $0.360^{* * *}$ & $1.377^{* * * *}$ & 0.322 & -0.421 & $0.748^{* * *}$ & $0.695^{* * *}$ & 15,706 \\
\hline Brandenburg & $-9.191 * * *$ & $0.386^{* * *}$ & $1.021^{* * *}$ & 1.071 & $0.978^{* *}$ & $0.303^{* * *}$ & $0.649^{* * *}$ & 31,068 \\
\hline Saxony-Anhalt & $-6.943^{* * *}$ & 0.0802 & $1.052^{* * *}$ & $\begin{array}{l}- \\
2.373^{* * *}\end{array}$ & $5.640^{* * *}$ & 0.109 & $0.473^{* * *}$ & 10,997 \\
\hline Thuringia & $-8.911 * * *$ & $0.324 * * *$ & $1.551^{* * *}$ & -0.116 & $1.410^{* * *}$ & $0.0826 * * *$ & $0.599 * * *$ & 105,908 \\
\hline Saxony & $-8.528 * * *$ & $0.220^{* * *}$ & $1.404^{* * *}$ & $1.729^{* * *}$ & $1.743^{* * *}$ & $0.144^{* * *}$ & $0.575^{* * *}$ & 104,938 \\
\hline All & $-8.017^{* * *}$ & $0.268^{* * *}$ & $1.474^{* * *}$ & $0.797^{* * *}$ & $1.010^{* * *}$ & $0.173^{* * *}$ & $0.579^{* * *}$ & 467,033 \\
\hline
\end{tabular}

The results for Table 7 are analogous to those reported in Table 6 with one exception; the influence of the share of fixed assets on excess growth financed by long-term financing is reversed. An explanation for this finding could be the design of the variable $R o L T A_{i}$. Since PPE is generally financed with long-term capital, calculating the return on shortterm capital (total assets less long-term liabilities) could lead to a lower probability of excess growth for the respective firms. Consider, for instance, a capital intensive business 
for which the return on short-term assets is, all other things equal, likely to be higher. Consequently, it will be more difficult for this firm to exceed the predicted growth rate which, in turn, would lead to a negative impact of PPE on excess growth.

Thus far, the design of our dependent variable only allowed us to estimate the impact of the degree of savings bank financing - not the impact of hausbank-relationships in general.

\section{Table 8: The influence of relationship lending on firms' excess growth}

Table 8 reports the regression results of the logit model with $L T G R O_{i}$ and $S T G R O_{i}$ as dependent variables. Both dependent variables are calculated as described above. The sample consists of 467,033 firm observations in all German federal states over the period 1996-2006. Instead of a metrical scaled covariate we use a dummy variable which takes the value one if a firm has more than $75 \%$ of all bank loans with a savings bank and zero otherwise. Furthermore, we control for the possibility that firms with a lower proportion of savings bank loans may have a hausbank-relationships with another bank by subsequently including a dummy if the proportion of savings banks loans is less than $25 \%$ for the respective firm. LEVERAGE is calculated as a firm's total debt over total assets. REGIONAL GDP is the average annual growth rate of the GDP in a given region. LERNER INDEX depicts the ability of the respective regional savings bank to charge prices above its marginal costs and as such a proxy for competition. Therefore a higher index stands for a lesser degree of competition. CAPITAL INTENSITY is calculated as fixed assets over total assets and controls for different industries such as service (low capital intensity) and production (high capital intensity). SIZE is the natural logarithm of a firm's total assets. Finally, the REGIONAL DUMMY controls for different conditions in the respective federal states. The estimated model is ExcessGrowth Firm $_{i}=\alpha_{i}+\beta_{1} S B_{i}+\beta_{2} S B_{i}+\beta_{3} L E_{i}+\beta_{4} G D P_{i}+\beta_{5} L I_{i}+\beta_{6} C I_{i}+\beta_{7} S I Z E_{i}+\beta_{8} R E G_{j}+$ $\epsilon_{i}$. The model is estimated with a robust Huber/White/sandwich estimator.

\begin{tabular}{|c|c|c|c|c|c|c|}
\hline Dependent Variable & STGRO & STGRO & STGRO & LTGRO & LTGRO & LTGRO \\
\hline $\begin{array}{l}\text { HAUSBANK DUMMY }(>75 \%) \\
\text { HAUSBANK DUMMY }(0<25 \%)\end{array}$ & $\begin{array}{c}-0.456^{* * *} \\
(0.008)\end{array}$ & $\begin{array}{c}0.0404^{* * *} \\
(0.009)\end{array}$ & $\begin{array}{c}0.0275^{* * *} \\
(0.010) \\
-0.0496^{* * *} \\
(0.019)\end{array}$ & $\begin{array}{c}-0.328^{* * *} \\
(0.007)\end{array}$ & $\begin{array}{c}0.141^{* * *} \\
(0.008)\end{array}$ & $\begin{array}{c}0.125^{* * *} \\
(0.009) \\
-0.0598^{* * *} \\
(0.017)\end{array}$ \\
\hline LEVERAGE & $\begin{array}{c}0.854^{* * *} \\
(0.016)\end{array}$ & $\begin{array}{c}1.574^{* * *} \\
(0.018)\end{array}$ & $\begin{array}{c}1.577^{* * *} \\
(0.018)\end{array}$ & $\begin{array}{c}0.803^{* * *} \\
(0.015)\end{array}$ & $\begin{array}{c}1.481^{* * *} \\
(0.017)\end{array}$ & $\begin{array}{c}1.485^{* * *} \\
(0.017)\end{array}$ \\
\hline REGIONAL GDP & $\begin{array}{c}1.097^{* * *} * \\
(0.163)\end{array}$ & $\begin{array}{c}0.806^{* * *} \\
(0.170)\end{array}$ & $\begin{array}{c}0.803^{* * *} * \\
(0.170)\end{array}$ & $\begin{array}{c}1.066^{* * *} * \\
(0.148)\end{array}$ & $\begin{array}{c}0.818^{* * *} \\
(0.155)\end{array}$ & $\begin{array}{c}0.815^{* * *} \\
(0.155)\end{array}$ \\
\hline LERNER INDEX & $\begin{array}{c}1.608^{* * *} * \\
(0.078)\end{array}$ & $\begin{array}{c}0.876^{* * *} \\
(0.082)\end{array}$ & $\begin{array}{c}0.875^{* * *} \\
(0.082)\end{array}$ & $\begin{array}{c}1.667 * * * \\
(0.073)\end{array}$ & $\begin{array}{c}1.035^{* * *} * \\
(0.076)\end{array}$ & $\begin{array}{c}1.034^{* * *} \\
(0.076)\end{array}$ \\
\hline CAPITAL INTENSITY & $\begin{array}{c}0.250^{* * *} \\
(0.013)\end{array}$ & $\begin{array}{c}-0.157^{* * *} \\
(0.014)\end{array}$ & $\begin{array}{c}-0.156^{* * *} \\
(0.014)\end{array}$ & $\begin{array}{c}0.519 * * * \\
(0.012)\end{array}$ & $\begin{array}{c}0.178^{* * *} \\
(0.013)\end{array}$ & $\begin{array}{c}0.180^{* * *} * \\
(0.013)\end{array}$ \\
\hline SIZE & & $\begin{array}{c}0.649 * * * \\
(0.004)\end{array}$ & $\begin{array}{c}0.649 * * * \\
(0.004)\end{array}$ & & $\begin{array}{c}0.572^{* * *} \\
(0.003)\end{array}$ & $\begin{array}{c}0.573^{* * *} \\
(0.003)\end{array}$ \\
\hline REGIONAL DUMMY & Yes & Yes & Yes & Yes & Yes & Yes \\
\hline CONST. & $\begin{array}{c}0.963^{* * *} \\
(0.103)\end{array}$ & $\begin{array}{c}-8.434^{* * *} \\
(0.117)\end{array}$ & $\begin{array}{c}-8.438^{* * *} \\
(0.117)\end{array}$ & $\begin{array}{c}0.555^{* * *} \\
(0.094)\end{array}$ & $\begin{array}{c}-7.834^{* * *} \\
(0.108)\end{array}$ & $\begin{array}{c}-7.840^{* * *} \\
(0.108)\end{array}$ \\
\hline N. of Obs. & 467,033 & 467,033 & 467,033 & 467,033 & 467,033 & 467,033 \\
\hline
\end{tabular}

Therefore we undertake a further robustness check on our measure for close borrowerlender relationships by substituting the continuous savings bank variable by two dummy variables which indicate a hausbank-relationship with either a savings bank or (potentially) another bank (Table 8). We do this to (i) account for the possibility that a firm with commitments less than $25 \%$ of its financial liabilities to savings banks may as well have a hausbank-relationship with, say, a cooperative bank and (ii) thus allow the relationship between savings bank credit and excess growth to be non-linear. Specifically, as 
an indicator of beneficial hausbank-relationships in general, we would expect a positive relation on growth for both variables. This expectation, however, rests on the assumption that firms with less than $25 \%$ savings bank loans do in fact have a dominant credit exposure to another single bank.

The first three columns of Table 8 show the influence of the (subsequently added) hausbank-dummy variables on firms' excess growth which only use internal funds, the second three columns the values when firms also have access to short-term borrowing. Since savings banks have a particular focus on smaller firms (see Table 1) we see that the variable size is critical to the results. Thus, when size is not accounted for the results are reverse. Interestingly, the impact of relationship lending is much stronger when firms have only limited access to long-term funding. This suggests that it is in particular the provision of long-term financing which constitutes the beneficial effects of hausbankrelationships. The finding that a proportion of savings bank loans below $25 \%$ is associated with lower firm growth seems somewhat peculiar. However, since we have no insights into the reasons that determine lower financial savings banks involvement (for instance if it is rather demand or supply driven) any interpretation would be speculative.

As a further robustness check of our results we repeat the regressions using a stratified sample to control for a possible bias due the high share of firms with hausbankrelationships in our data. Moreover, we use a Tobit approach (Model 2, Table 9) and measure the excess growth variable for firms that are constraint by long-term financing not as dummy but as metrically scaled variable. We find that the positive influence of hausbank-relationships on excess growth remains unchanged. 
Table 9 presents additional regressions to validate the robustness of our results under different specifications. First, we control for the possibility that our results may be biased due to the large share of firms with hausbank-relationships in our sample. Therefore we generate a stratified sample with 50,000 observations from each quartile of the proportion of savings banks loans. Model (1) then re-runs the full regression from Table 8 with $L T G R O_{i}$ as independent variable. $L T G R O_{i}$ equals one if a firm exceeds its short-term financed growth rate in a given year and zero otherwise. In model (2), on the other hand, $L T G R O_{i}$ is not calculated as dummy but as metrically scaled variable giving the degree by which a firm exceeds its short-term financed growth rate. This model uses a Tobit approach with the sample censored at zero due to the consideration of excess growth only. The estimated model is $L T G R O_{i}=\alpha_{i}+\beta_{1} S B_{i}+\beta_{2} S B_{i}+\beta_{3} L E_{i}+\beta_{4} G D P_{i}+$ $\beta_{5} L I_{i}+\beta_{6} C I_{i}+\beta_{7} S I Z E_{i}+\beta_{8} R E G_{j}+\epsilon_{i}$. The model is estimated with a robust Huber/White/sandwich estimator.

\begin{tabular}{l|cc}
\hline Model & $(1)$ & $(2)$ \\
Dependent Variable & LTGRO & LTGROmetr. \\
\hline HAUSBANK DUMMY $(>75 \%)$ & $0.144^{* * *}$ & $0.0772^{* * *}$ \\
HAUSBANK DUMMY $(0<25 \%)$ & $(0.015)$ & $(0.019)$ \\
& $-0.131^{* * *}$ & $-0.0627^{* * *}$ \\
LEVERAGE & $(0.019)$ & $(0.021)$ \\
& $1.485^{* * *}$ & $1.258^{* * *}$ \\
REGIONAL GDP & $(0.029)$ & $(0.036)$ \\
& $1.336^{* * *}$ & -0.163 \\
LERNER INDEX & $(0.256)$ & $(0.284)$ \\
CAPITAL INTENSITY & $1.031^{* * *}$ & $0.372^{* *}$ \\
SIZE & $(0.127)$ & $(0.153)$ \\
& $0.132^{* * *}$ & 0.022 \\
REGIONAL DUMMY & $(0.022)$ & $(0.026)$ \\
CONST. & $0.554^{* * *}$ & $0.275^{* * *}$ \\
& $(0.005)$ & $(0.005)$ \\
\hline N. of Obs. & Yes & Yes \\
\hline Standard errors in parentheses & $-7.245^{* * *}$ & $-6.193^{* * *}$ \\
$*$ p $<0.10, * *$ p $<0.05, * * * p<0.01$ & $(0.175)$ & $(0.172)$ \\
\hline & 180,503 & 180,503 \\
\hline
\end{tabular}

\section{Conclusion}

This study investigates the contribution of public banks to the funding and beneficial development of SME. To this end we examine whether close borrowers-lender relationships help firms to grow faster than by relying on internal resources or short-term financing only.

In a first step, the descriptive evidence which yields some interesting findings about the properties of hausbank-relationships is presented: First, smaller firms are more likely to have hausbank-relationships. The median size of such firms is $€ 549,639$ whereas the median size of firms with multiple lending relations is $€ 1,271,998$. Second, the longterm liabilities of firms with hausbank-relationships almost double those with multiple relationships while the overall leverage is about the same. Third, single bank depended borrowers seem to have less problems accommodating their financial obligations (including leases) as depicted by their higher interest coverage ratios.

Based thereon, we follow cross-country firm-level studies by Demirgüç-Kunt and Maksimovic $(1998,2002)$ and develop a measure of predicted growth based on firms' internal- 
and short-term funds. We then use these measures to create dummy variables which indicate whether firms exceeded their predicted growth rates and subsequently predict the indicator variables by the share of savings banks loans as well as hausbank-dummy covariates.

We find that strong ties between firms and savings banks enhance access to (longterm) capital and ultimately spur firm growth. These results hold for different model and hausbank-proxy specifications and are in line with Petersen and Rajan (1994) and Berger and Udell (1995) for small U.S. firms and Elston (1996) for German manufacturing firms. The results further suggest that it is in particular the provision of long-term financing which constitutes the beneficial effects of hausbank-relationships. As further research it would be interesting to investigate whether these beneficial features are constituted by hausbank-relationships in general or or if they are rather a particular characteristic of savings banks. 


\section{A Additional Tables}

\begin{tabular}{|c|c|c|c|c|c|c|c|c|}
\hline \multicolumn{9}{|c|}{ Table 10: Correlation matrix } \\
\hline & 1 & 2 & 3 & 4 & 5 & 6 & 7 & 8 \\
\hline $\operatorname{IGR}(1)$ & 1 & & & & & & & \\
\hline SGR (2) & 0.0001 & 1 & & & & & & \\
\hline Proportion of savings banks loans (3) & $0.003^{*}$ & $0.004^{*}$ & 1 & & & & & \\
\hline Leverage (4) & $-0.0055^{*}$ & 0.0009 & $0.076^{*}$ & 1 & & & & \\
\hline GDP growth (5) & 0.0006 & $0.003^{*}$ & $0.007^{*}$ & $0.005^{*}$ & 1 & & & \\
\hline Lerner Index (6) & 0.0012 & $0.003^{*}$ & $0.015^{*}$ & $0.028 *$ & $0.0069^{*}$ & 1 & & \\
\hline Capital intensity (7) & -0.0006 & -0.001 & $0.015^{*}$ & $-0.093^{*}$ & 0.0028 & $-0.053^{*}$ & 1 & \\
\hline Size (8) & $-0.0082^{*}$ & $-0.0157^{*}$ & $-0.309 *$ & $-0.192^{*}$ & $0.007^{*}$ & $0.0362^{*}$ & $0.145^{*}$ & 1 \\
\hline
\end{tabular}

\section{Table 11: Results of efficiency and Lerner estimates}

The Lerner index components, average revenues and marginal cost, are estimated from stochastic cost and profit panel analysis. Multiple outputs of the banks as well as financial expenses are explicitly accounted for when estimating efficiency and Lerner indices. The data is obtained from the German Savings Banks Association's (DSGV) Bank Performance Comparison and covers the period from 1996 to 2006. For a more in-depth discussion on the calculation of Lerner indices see Koetter and Vins (2008).

\begin{tabular}{lrcccccc}
\hline Variable & & Mean & SD & Min & $25 \% \mathrm{p}$ & $75 \% \mathrm{p}$ & Max \\
\hline Cost efficiency & $\mathrm{CE}$ & 0.828 & 0.039 & 0.519 & 0.808 & 0.855 & 0.919 \\
Profit efficiency & $\mathrm{PE}$ & 0.534 & 0.096 & 0.038 & 0.476 & 0.606 & 0.757 \\
Lerner index & Lerner & 0.237 & 0.057 & 0.064 & 0.196 & 0.277 & 0.52 \\
\hline
\end{tabular}

Notes: 4,934 observations in the period 1996-2006. 


\section{References}

Agarwal, Rajshree, and Julie Ann Elston. 2001. "Bank Firm Relationships, Financing and Firm Performance in Germany." Economics Letters 72:225-232.

Audretsch, David B., and Julie Ann Elston. 2002. "Does firm size matter? Evidence on the impact of liquidity constraints on firm investment behavior in Germany." International Journal of Industrial Organization 20:1-17.

Barclay, Michael J., and Erwan Morellec. 2006. "On the Debt Capacity of Growth Options." Journal of Business 79 (1): 37-60 (January).

Berger, Allen L., F. Klapper, Leora, and Gregory F. Udell. 2001. "The ability of banks to lend to informationally opaque small businesses." Journal of Banking ES Finance 25:2127-2167.

Berger, Allen L., Leora F. Klapper, Maria Soledad Martinez Peria, and Rida Zaidi. 2007. "Does market size structure affect competition? The case of small business lending." Journal of Financial Intermediation, vol. Article in press.

Berger, Allen N., Richard J. Rosen, and Gregory F. Udell. 2007. "Does market size structure affect competition? The case of small business lending." Journal of Banking E Finance 31 (1): 11-33 (January).

Berger, Allen N, and Gregory F Udell. 1995. "Relationship Lending and Lines of Credit in Small Firm Finance." Journal of Business 68 (3): 351-81 (July).

Boot, Arnoud W.A., and Anjan V. Thakor. 2000. "Can Relationship Banking survive Competition?" The Journal of Finance 55(2) (98-038/2): 679-713 (April).

Boyd, John H., and Gianni De Nicolã. 2005. "The Theory of Bank Risk Taking and Competition Revisited." Journal of Finance 60 (3): 1329-1343 (06).

Buch, Claudia, and Joerg Doepke. 2008. "Growth, volatility, and credit market imperfections: evidence from German firms." Journal of Economic Studies 35 (3): 263-277 (July).

Cole, Rebel A. 1998. "The importance of relationships to the availability of credit." Journal of Banking \& Finance 22:959-977.

D'Auria, Claudio, Antonella Foglia, and Paolo Marullo Reedtz. 2007. "Bank interest rates and credit relationships in Italy." Journal of Banking Ef Finance 23:1067-1093. 
Demirgüç-Kunt, Asli, and Vojislav Maksimovic. 1998. "Law, Finance, and Firm Growth." Journal of Finance 53 (6): 2107-2137 (December).

Demirgüç-Kunt, A., and V. Maksimovic. 2002. "Funding Growth in Bank-Based and Market-Based Financial Systems: Evidence from Firm Level Data." Journal of Financial Economics 65:337-363.

Demirgüç-Kunt, Asli, and Vojislav Maksimovic. 1999. "Institutions, financial markets, and firm debt maturity." Journal of Financial Economics 54 (3): 295-336 (December).

- 2001, October. "Firms as financial intermediaries - evidence from trade credit data." Policy research working paper series 2696, The World Bank.

Elsas, Ralf. 2005. "Empirical determinants of relationship lending." Journal of Financial Intermediation 14 (1): 32-57 (January).

Elston, Julie Ann. 1996, January. "Investment, Liquidity Constraints and Bank Relationships: Evidence from German Manufacturing Firms." Cepr discussion papers 1329, C.E.P.R. Discussion Papers.

González, Raquel Lago, Jose A. Lopez, and Jesús Saurina. 2007. "Determinants of access to external finance: evidence from Spanish firms." Working paper series 200722, Federal Reserve Bank of San Francisco.

Hackethal, Andreas, R. H. Schmidt, and M. Tyrell. 1999. "Disintermediation and the Role of Banks in Europe: An International Comparison." Journal of Financial Intermediation 8:36-67.

Higgins, R.C. 1977. "How much growth can a firm afford?" Financial Management $6: 3-16$.

Iannotta, Giuliano, Giacomo Nocera, and Andrea Sironi. 2007. "Ownership structure, risk and performance in the European banking industry." Journal of Banking \& Finance, vol. Article in press.

Jensen, Michael C. 1986. "Agency Costs of Free Cash Flow, Corporate Finance, and Takeovers." American Economic Review 76 (2): 323-29 (May).

Koetter, Michael, Thorsten Nestmann, Stéphanie Stolz, and Michael Wedow. 2006. "Two 
decades of German banking: Still overbanked and unprofitable." Kredit und Kapital 39 (4): 497-511.

Koetter, Michael, and Oliver Vins. 2008, November. "The Quiet Life Hypothesis in Banking - Evidence from German Savings Banks." Working paper series: Finance and accounting 190, Department of Finance, Goethe University Frankfurt am Main.

Koetter, Michael, and Michael Wedow. 2006. "Finance and Growth in a Bank-Based Economy: Is it Quantity or Quality that Matters?" Bundesbank Discussion Paper Series 2, vol. 02/2006.

Krahnen, Jan Pieter, and Reinhard H. Schmidt, eds. 2004. The German Financial System. Oxford.

Lucchetti, R., L. Papi, and A. Zazzaro. 2001. "Bank's Inefficiency and Economic Growth: A Micro-Macro Approach." Scottish Journal of Political Economy 48 (4): 400-424.

Ludwig, Udo; Hall, John. 2006. "Economic convergence across German regions in light of empirical findings." Cambridge Journal of Economics 30:1-13.

Micco, Alejandro, Ugo Panizza, and Monica Yanez. 2007. "Bank ownership and performance. Does politics matter?" Journal of Banking \& Finance 31:219-241.

Myers, Stewart C. 1976. "Determinants of corporate borrowing." Working papers 875-76., Massachusetts Institute of Technology (MIT), Sloan School of Management.

Petersen, Mitchell A, and Raghuram G Rajan. 1994. "The Benefits of Lending Relationships: Evidence from Small Business Data." Journal of Finance 49 (1): 3-37 (March).

—. 1995. "The Effect of Credit Market Competition on Lending Relationships." The Quarterly Journal of Economics 110 (2): 407-43 (May).

Rajan, Raghuram G, and Luigi Zingales. 1998. "Financial Dependence and Growth." American Economic Review 88 (3): 559-86 (June).

Samitas, Aristeidis G., and Dimitris F. Kenourgios. 2004. "Entrepreneurship, small and medium size business markets and European economic integration." Journal of Policy Modeling 27:363-374.

Sharpe, Steven A. 1990. "Asymmetric Information, Bank Lending, and Implicit Con- 
tracts: A Stylized Model of Customer Relationships." Journal of Finance 45 (4): 1069-87 (September).

Whited, Toni M. 1992. "Debt, Liquidity Constraints, and Corporate Investment: Evidence from Panel Data." Journal of Finance 47 (4): 1425-60 (September).

Zarutskie, Rebecca. 2003. "Does bank competition affect how much firms can borrow? new evidence from the U.S." Proceedings, no. May:121-136. 